\title{
Lesions of The Eyeball and Ocular Adnexa - Our Experience Over A Period of 18 Months
}

\author{
Shailesh Vartak, Amrita Neelakantan and Urmi Chakravarty-Vartak* \\ Lokmanya Tilak Municipal Medical College and General Hospital Sion, Mumbai-400022 Maharashtra, India.
}

\begin{abstract}
Background: The eyeball is a unique sensory organ, with a varied spectrum of lesions, which are rare with subtle presentation,thus posing diagnostic challenges.Our aim is to evaluate histomorphology of lesions of eye and ocular adnexa, classify and compare with other studies.

Methods: All biopsies and specimens of eyelid, eyeball and orbital lesions received in histopathology section of our Pathology department between January 2017 and June 2018 were analysed and a total 43 cases were evaluated.

Results: The age distribution of cases analysed ranged from 6 years to 85 years with mean age of 39 years and equal gender distribution. Neoplastic lesions (53.49\%) were more common than non-neoplastic lesions. Among neoplastic lesions, benign (56.52\%) were more common than malignant. The most common non-neoplastic lesion was zygomycosis of orbit (75\%), epidermal cyst in eyelid (30\%) and granulation tissue in eyeball $(50 \%)$. The only benign tumour in orbit was meningioma. The most common benign tumour in eyelid was hemangioma $(50 \%)$ and in eyeball, we encountered 1 pigmented nevus of conjunctiva and 1 apocrine hidrocystoma.Common malignant eyelid tumours were basal cell carcinomaand sebaceous carcinoma(33.33\% each), whereas in orbit we received 1 basal cell carcinoma and 1 adenoid cystic carcinoma. In eyeball, we encountered 1 basal cell carcinoma and 1 squamous cell carcinoma of conjunctiva.
\end{abstract}

Conclusion: Most of the studies done in this arena focus on either adnexa or orbit alone, and through our study we have tried to understand the frequency of occurrence and histomorphology of all lesions pertaining to eyeball, orbit and adnexa.

\section{Keywords: Ocular Adnexa, Eyeball Lesions}

\section{Introduction}

The eyeball is a unique and special sensory organ. It exhibits diverse histologic structures. Many of the lesions arising from the eyeball and its adnexa are rare. Moreover, their presentation is subtle and this makes their diagnosis a challenge. Therefore, knowledge of the anatomy of the eyeball and the spectrum of lesions arising from it is important.

The aim of our study is to evaluate the histomorphological spectrum of lesions of entire eyeball and ocular adnexa, classify lesions as non-neoplastic or neoplastic (benign \& malignant) and to compare our results with other studies.

\section{Materials and Methods}

Our study was a retrospective study carried out by including cases encountered during the period January 2017 to June 2018 , a duration of 18 months.

All biopsies and enucleation specimens received in the surgical pathology section of our pathology department were included in the study. A total of 43 cases were received during the study period. Relevant clinical history and radiological findings were obtained with each specimen/biopsy received. Size, shape and consistency of each specimen was recorded. The large specimens received were adequately fixed in formalin. They were then cut sagitally and extensively sampled and appropriate sections were taken according to the site of lesion. Small biopsies were fixed overnight in formalin and completely submitted. The tissue was embedded in paraffin blocks in proper orientation. 5-7 um thick sections were taken. They were processed and stained with Haematoxylin and Eosin $(H \&$ E) stain. Special stains and Immunohistochemistry (IHC) were performed wherever necessary.

\section{Results}

Our study was carried out over a period of 18 months. The total numbers of cases studied were 43 .

The most common age group affected was $40-60$ years with 14 cases $(32.56 \%)$ seen in this age group. Sex distribution was almost equal with slight male preponderance (1.2:1).

Maximum number of lesions were confined to the eyelid and lacrimal glands, and comprised of $55.81 \%$ of all lesions. This was followed by $27.91 \%$ lesions in the eyeball and $16.28 \%$ lesions in the orbit.

In eyelid and eyeball, the neoplastic lesions outnumbered the non-neoplastic whereas in orbit, both were equal in number. 
Among neoplastic lesions, benign lesions were more than malignant in the eyelid and eyeball. In the orbit, malignant lesions were more than benign.

Among eyeball lesions, granulation tissue was the most commonly received non-neoplastic lesion. The benign lesions received were 1 case each of benign fibrosseus lesion, pigmented nevus, conjunctival cyst and apocrine hidrocystoma. The two malignant cases received were 1 case of basal cell carcinoma and 1 case of squamous cell carcinoma. Epidermal cyst was the most common nonneoplastic lesion of the eyelid.

The most common benign lesion of the eyelid was hemangioma of which we received 4 cases and two cases each were received of basal cell carcinoma and sebaceous carcinoma. Zygomycosis was the most common nonneoplastic lesion of the orbit. The only benign orbital lesion in our study was orbital meningioma. One case each of basal cell carcinoma and adenoid cystic carcinoma were the malignant lesions seen in the orbit.

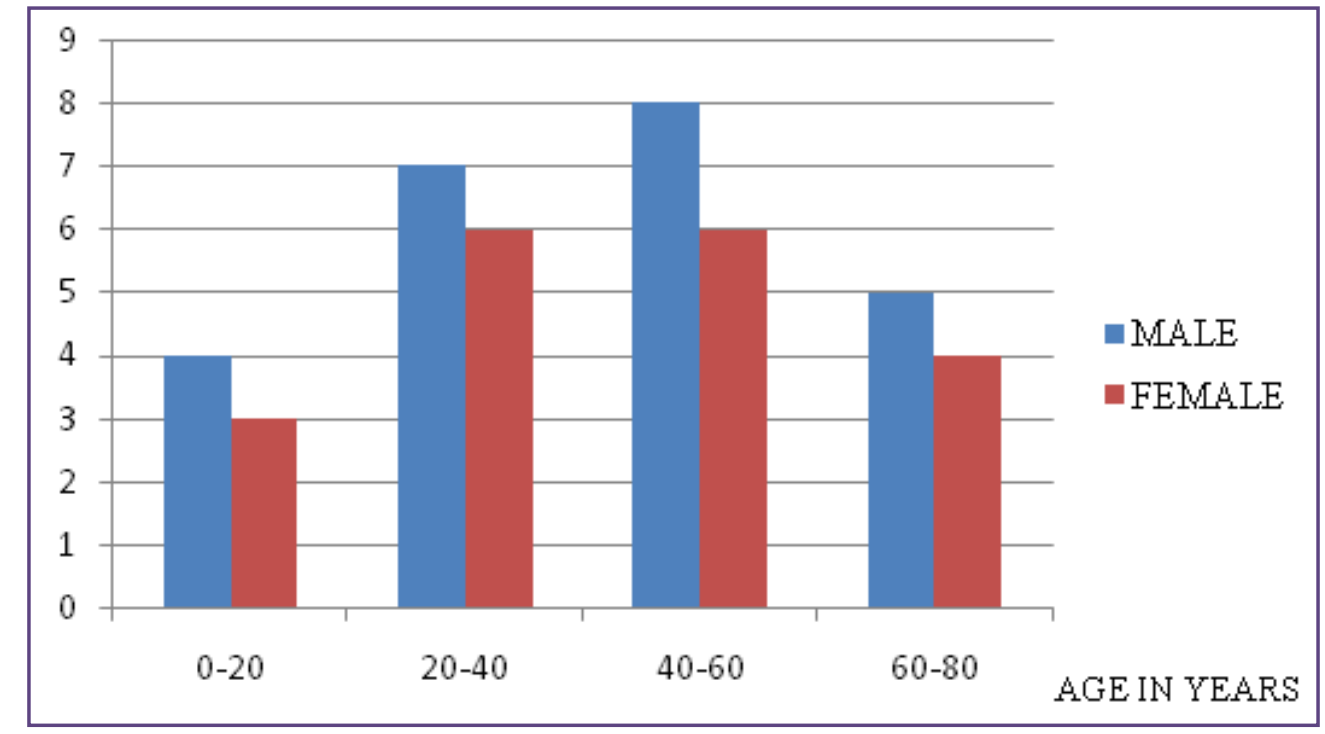

GRAPH 1 : DEMOGRAPHIC PROFILE OF LESIONS

Table 1: Distribution Of Cases-Non Neoplastic And Neoplastic (Benign And Malignant)

\begin{tabular}{|c|c|c|c|c|}
\hline & \multirow{2}{*}{ NON-NEOPLASTIC } & \multicolumn{2}{|c|}{ NEOPLASTIC } & \multirow{2}{*}{ TOTAL } \\
\cline { 3 - 5 } & & BENIGN & 02 & 12 \\
\hline EYEBALL & 06 & 04 & 06 & $24.91 \%)$ \\
\hline EYELID+LG & 10 & 08 & 02 & $(55.81 \%)$ \\
\hline ORBIT & 04 & 01 & 07 & $(16.28 \%)$ \\
\hline TOTAL & $\mathbf{2 0}$ & $\mathbf{1 3}$ & $\mathbf{1 0}$ & $\mathbf{4 3}$ \\
\hline
\end{tabular}

Table 2: Site Distribution Of Lesions.

\begin{tabular}{|c|c|c|c|c|}
\hline & Non Neoplastic & Benign & Malignant & Total \\
\hline \multirow[t]{4}{*}{ Eyeball } & Granulation Tissue -3 & $\begin{array}{c}\text { Benign Fibro } \\
\text { osseous lesion - } 1\end{array}$ & Basal Cell Carcinoma -1 & \multirow[t]{4}{*}{12} \\
\hline & Zygomycosis - 2 & $\begin{array}{l}\text { Pigmented } \\
\text { Nevus - } 1\end{array}$ & $\begin{array}{l}\text { Squamous Cell } \\
\text { Carcinoma }-1\end{array}$ & \\
\hline & Normal Histology -1 & $\begin{array}{c}\text { Conjunctival } \\
\text { Cyst }-1\end{array}$ & ---- & \\
\hline & $\begin{array}{ll}---- \\
-\cdots-\end{array}$ & Apocrine Hidrocystoma - 1 & ----- & \\
\hline
\end{tabular}




\begin{tabular}{|c|c|c|c|c|}
\hline & Non Neoplastic & Benign & Malignant & Total \\
\hline \multirow{6}{*}{$\begin{array}{l}\text { Eyelid + } \\
\text { Lacrimal } \\
\text { Gland }\end{array}$} & $\begin{array}{l}\text { Epidermal } \\
\text { Cyst -3 }\end{array}$ & Hemangioma - 4 & Basal Cell Carcinoma -2 & \multirow[t]{6}{*}{24} \\
\hline & Chalazion -2 & Eosinophilic Granuloma - 1 & Sebaceous Carcinoma -2 & \\
\hline & Molluscum -2 & Pleomorphic Adenoma - 1 & Malignant Melanoma -1 & \\
\hline & $\begin{array}{c}\text { Arteriovenous } \\
\text { Malformation -1 }\end{array}$ & Myxoma - 1 & $\begin{array}{c}\text { Squamous Cell } \\
\text { Carcinoma }-1\end{array}$ & \\
\hline & $\begin{array}{c}\text { Chronic Dacryocystitis } \\
-1\end{array}$ & Seborrheic Keratosis-1 & ----- & \\
\hline & Granulation Tissue -1 & ----- & ----- & \\
\hline \multirow[t]{2}{*}{ Orbit } & Zygomycosis - 3 & Meningioma - 1 & Basal Cell Carcinoma -1 & \multirow[b]{2}{*}{7} \\
\hline & $\begin{array}{c}\text { Arterio Venous } \\
\text { Malformation - } 1\end{array}$ & ----- & Adenoid Cystic Carcinoma -1 & \\
\hline Total & 20 & 13 & 10 & 43 \\
\hline
\end{tabular}

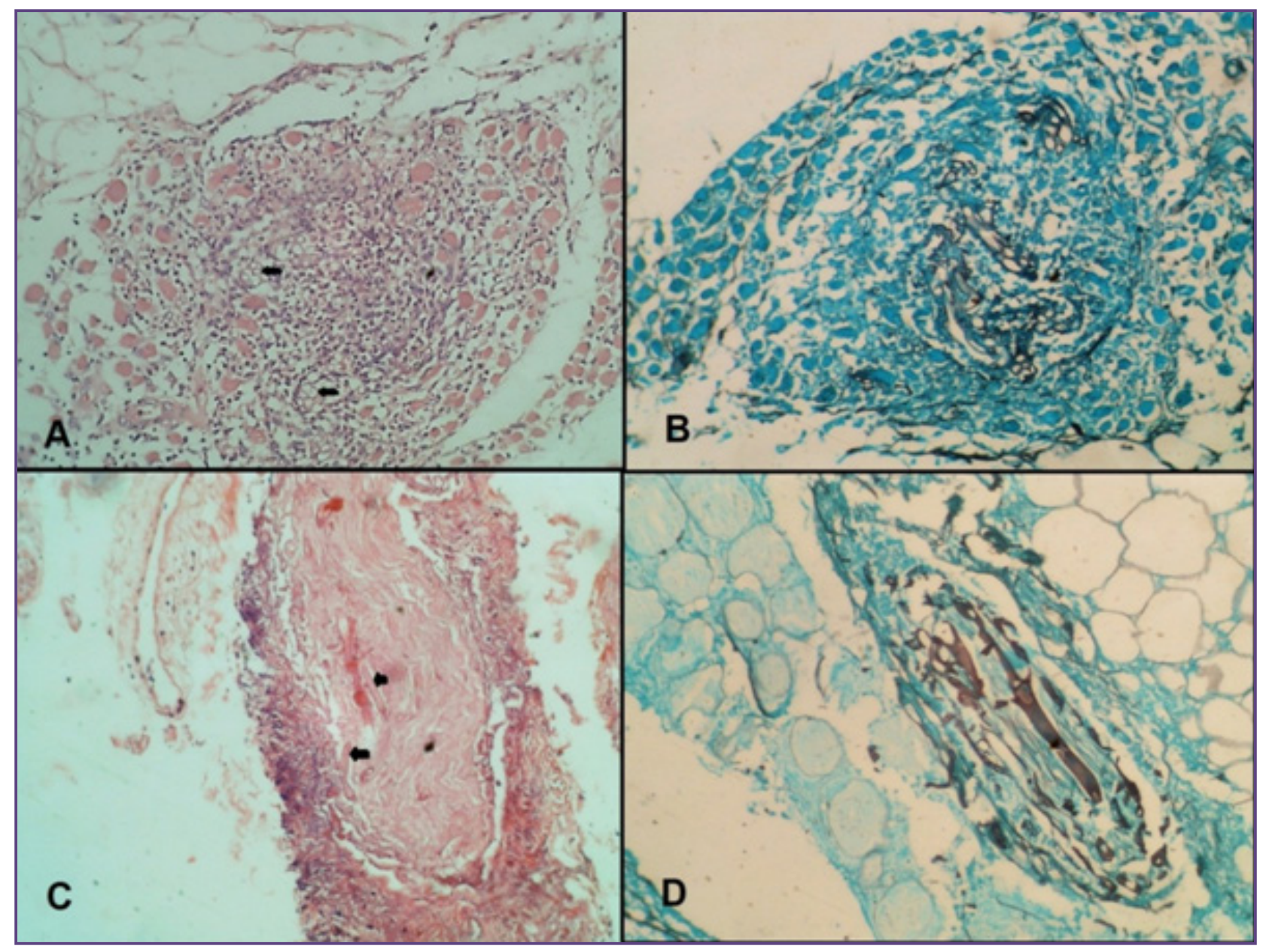

Fig. 1: A - Zygomycosis showing soft tissue and muscle invasion (H \& E 100 X).B - Zygomycosis showing soft tissue and muscle invasion (GMS 100 X)C - Zygomycosis showing optic nerve invasion (arrow) (H \& E 100 X) D - Special stain showing morphology of the fungus (GMS $400 \mathrm{X}$ ). 


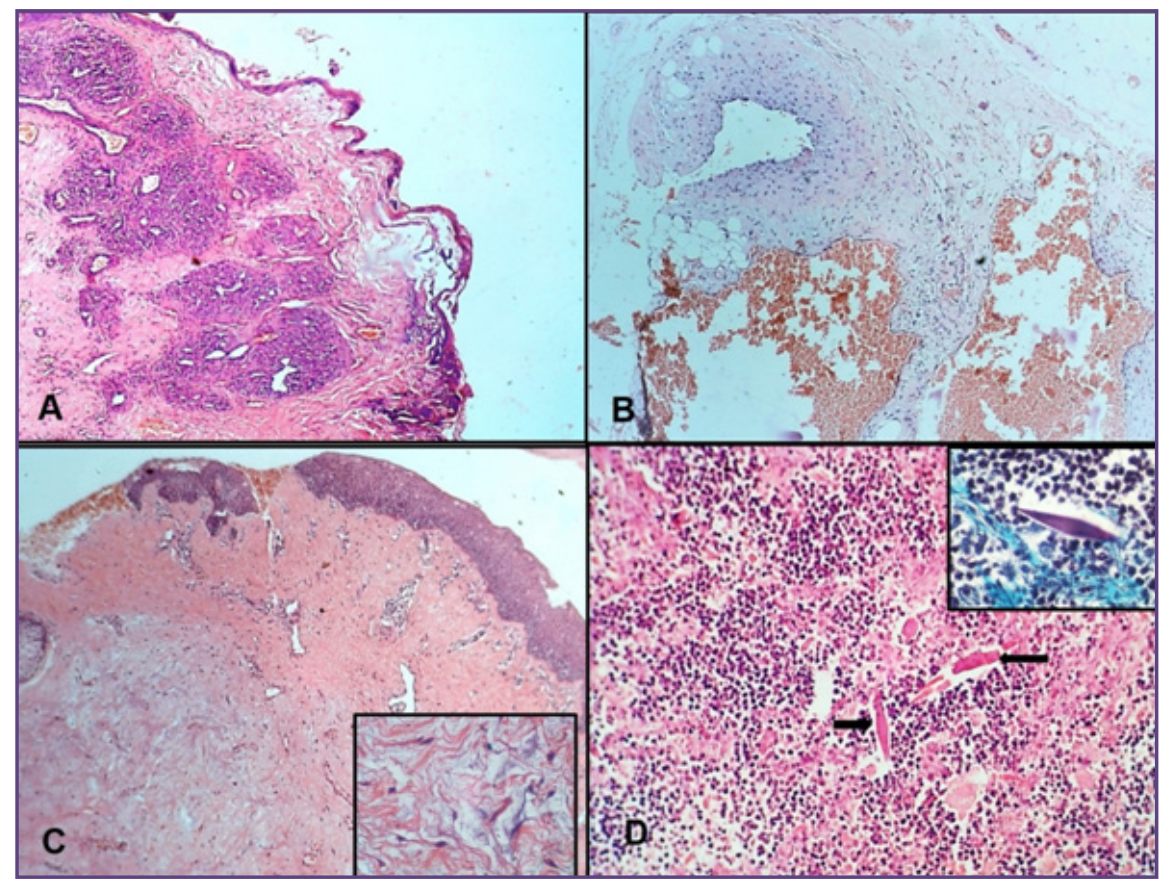

Fig.2A - Lobular Capillary Haemangioma. Lobules of capillary sized blood vessels in the subepithelial region (H \& E $40 \mathrm{X}$ ) B - Arterio-Venous Malformation. Variable-calibre blood vessels showing congestion (H \& E 100X).C - Myxoma. Well-defined hypo-cellular myxoid area seen in the subepithelialconnectivetissue (H\&E 40X). Inset shows myxoid area in the connective tissue.(H\&E 400X).D - Eosinophilic Granuloma. Mixed inflammation seen composed of eosinophils,histiocytes, neutrophils and occasional lymphocytes with Charcot-Leyden crystals(H\&E 100X). Inset (upper left) shows eosinophils and histiocytes (H\&E 400X).Inset (lower right) shows Charcot-Leyden crystals - (Trichrome stain 400X).

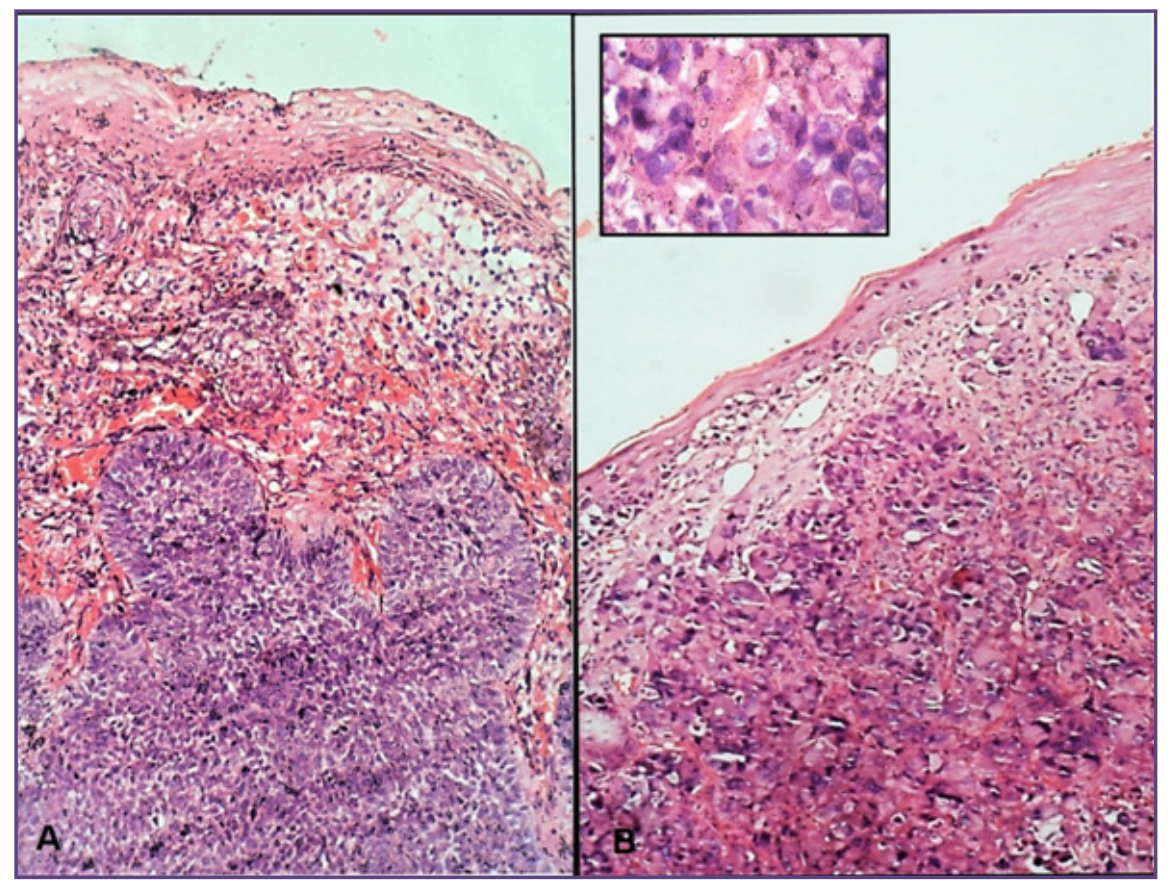

Fig. 3: A - Basal Cell Carcinoma. Nests of basaloid cells with peripheral palisading (H\&E 100X).B - Malignant Melanoma. Diffusely arranged pleomorphic oval to polygonal cells andmitotic figures, (H\&E 100X). Inset shows pleomorphic cells with moderateeosinophilic cytoplasm, enlarged, vesicular nuclei and prominent cherry-red nucleoli(H\&E 400X). 


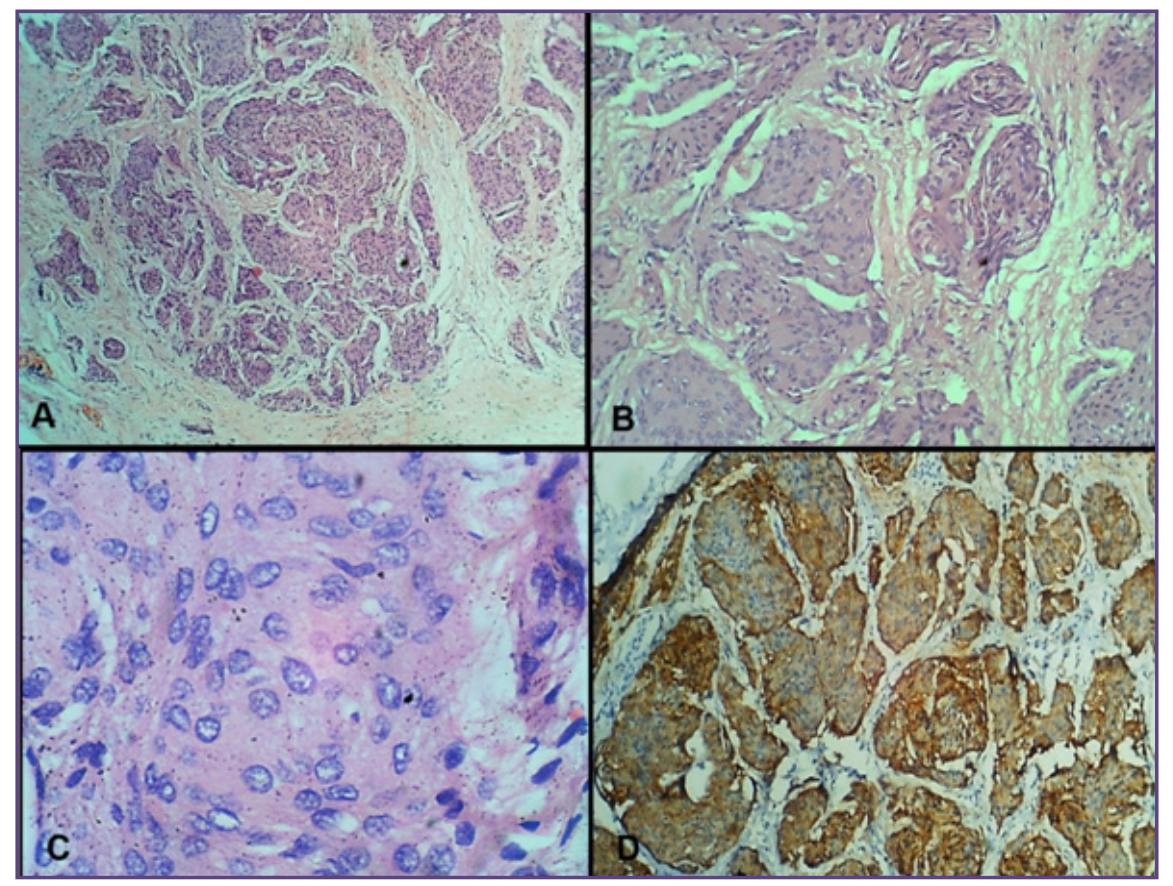

Fig. 4: Meningioma. A and B: Round to oval monomorphic looking cells which are arranged in whorled pattern (A - H\&E 40X; B - H\&E 100X).C and D: the cells are monomorphic, round to oval, with moderate eosinophilic cytoplasm, benign-looking round nuclei and inconspicuous nucleoli(H\&E 400X).IHC- cells show membrane positivity for Epithelial Membrane Antigen (EMA 100X).

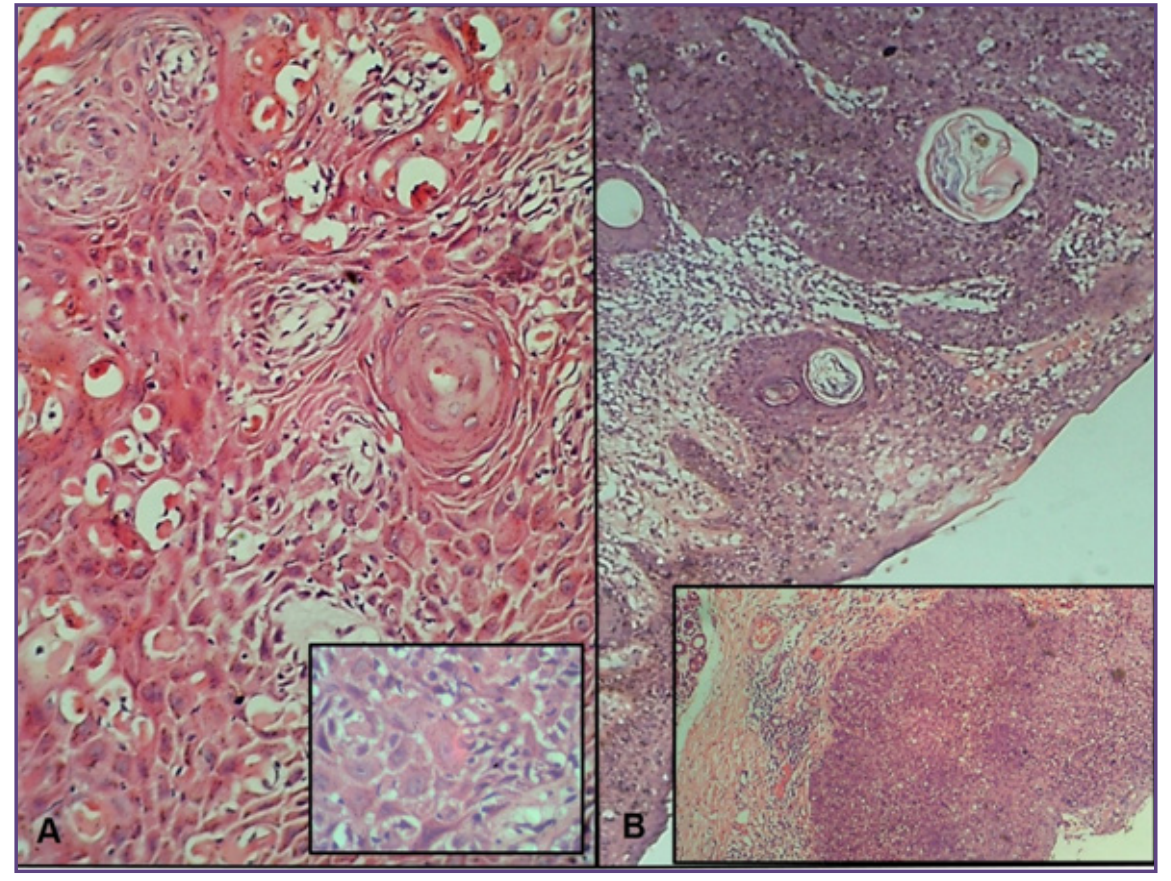

Fig. 5:A - Squamous Cell Carcinoma. Polygonal cells showing individual cell keratinisation and keratin pearl formation (H\&E 100X). Inset shows pleomorphic cells with moderate eosinophilic cytoplasm and individual cell keratinisation. Nuclei are enlarged with prominent nucleoli (H\&E 400X).B - Sebaceous Carcinoma. Round to oval cells arranged in nests around the hairfollicles with interspersed lymphocytic inflammation (H\&E 100X). Inset shows round to oval cells with abundant vacuolated eosinophilic cytoplasm and inconspicuousnucleoli (H \& E 400X). 


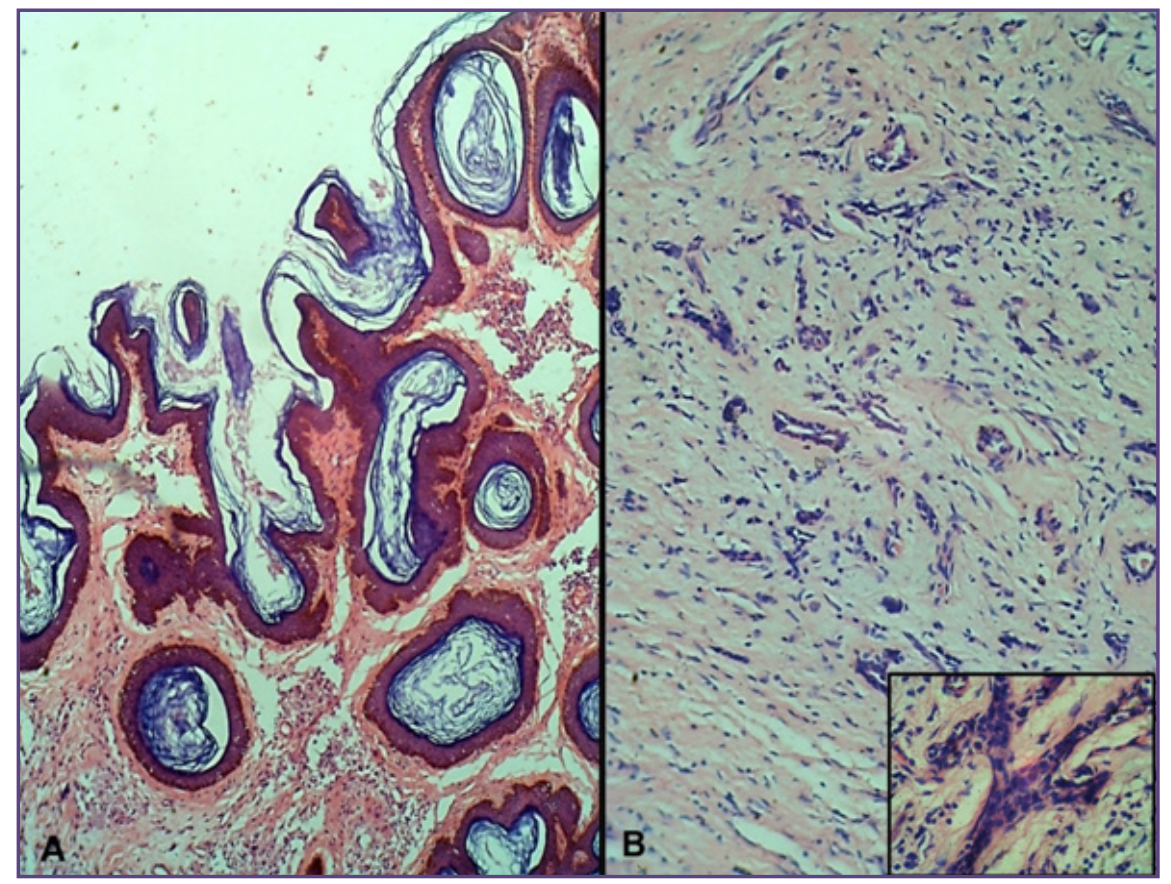

Fig. 6:A - Seborrheic Keratosis. Skin showing hyperplasia and hyperkeratosis withpseudohorn cysts seen. (H \& E 100X)B Adenoid Cystic Carcinoma. Round to oval cells arranged in tubular pattern in aloose myxoid stroma (H\&E 100X). Inset shows tubular arrangement of cells withmyxoid stroma showing minimal lymphocytic inflammation (H\&E 400X).

\section{Discussion}

Our study was carried out over a period of 18 months. A total of 43 cases were studied.

Neoplastic lesions were more than non-neoplastic lesions, and among neoplastic lesions benign were more than malignant.

We found that most of the cases in our study were falling in the 40-60 years age bracket with slight male preponderance.

A similar study was conducted by Yashita et al in 2014 in a tertiary care centre in Central India.$^{[1]}$ They studied a total of 488 cases over a period of 7 years. In their study they received maximum number of cases in the age group of $0-20$ years, amounting to $44.88 \%$ of the total number of cases. Gender distribution was equal. The commonest age bracket of Chauhan et al and Sheikh et al were comparable to our study. ${ }^{[2,3]}$

We had 11 eyeball lesions in our study. The most common lesion in the eyeball in our study was granulation tissue of which we received 3 cases, which was classified as non-neoplastic. Among benign lesions in the eyeball, we received 1 case each of pigmented nevus and apocrine hidrocystoma. Malignant lesions were 2 in number, one each of basal cell carcinoma and squamous cell carcinoma.

Most common lesion in the eyeball as observed by Yashita et al in their study was conjunctival cyst. ${ }^{[1]}$ Chauhan et al,
Sheikh et al and N Ud Din et al also observed conjunctival cyst to be the most common eyeball lesion in their respective studies. ${ }^{[2,3,4]}$ Silas et al, in their study, found squamous cell carcinoma to be the commonest malignant tumour of the conjunctiva. ${ }^{[9]}$ However, in series by Kapurdov A et al, basal cell carcinoma was the commonest $(68.79 \%)$ followed by squamous cell carcinoma (12.1\%) and melanoma (5.1\%). ${ }^{[13]}$ Conjunctival melanoma was also reported as a common malignant tumour in studies conducted by Marshall et al, Mondal et al and Thakur et al. ${ }^{[18,19,20]}$

Zygomycosis was the most common lesion in the orbit in our study, classified under non-neoplastic lesions. We had 1 case of adenoid cystic carcinoma and basal cell carcinoma each, classified under malignant lesions.

Yashita et al in their study noted more malignant lesions than benign, with Non-Hodgkin's lymphoma accounting for 13 cases and Retinoblastoma accounting for 9 cases of all their orbital lesions. ${ }^{[1]}$ This high number could be attributed to the fact that theirs was a pediatric specialty centre with paediatric ophthalmic cases outnumbering the adult cases. Monsudi et al in their study observed hemangioma as their most common benign lesion. ${ }^{[7]}$ Tendler et al in their study observed a rare case of orbital meningioma, which was comparable to our study. ${ }^{[1]}$

Among eyelid and lacrimal gland lesions, epidermal cyst was the most common non-neoplastic lesion with 3 cases, 
Table 3: Comparison Of Age Parameter With Other Studies.

\begin{tabular}{|c|c|c|c|c|}
\hline & $\begin{array}{c}\text { Our study } \\
\text { (18 months }-43 \text { cases) }\end{array}$ & $\begin{array}{l}\text { Yashita et al } 2014 \\
(7 \text { year } 488 \text { cases })^{[1]}\end{array}$ & $\begin{array}{c}\text { Chauhan SC et al } 2012 \\
\text { (1 year-100 cases) }^{[2]}\end{array}$ & $\begin{array}{l}\text { Sheikh et al } 2010 \\
(5 \text { yr-200 cases })^{[3]}\end{array}$ \\
\hline $0-20$ years & $18.60 \%(07)$ & $44.87 \%(219)$ & $21 \%$ & $18 \%(36)$ \\
\hline $21-40$ years & $32.55 \%(13)$ & $15.77 \%(77)$ & $37 \%$ & $30 \%(60)$ \\
\hline $41-60$ years & $27.90(14)$ & $14.13 \%(69)$ & $23 \%$ & $28 \%(56)$ \\
\hline 61 years and above & $20.90 \%(09)$ & $25.20 \%(123)$ & $19 \%$ & $24 \%(48)$ \\
\hline $\begin{array}{c}\text { Gender } \\
\text { Distribution }\end{array}$ & $1.1: 1$ & $1: 1$ & $1.5: 1$ & $1.4: 1$ \\
\hline
\end{tabular}

Table 4: Comparison Of Eyeball Lesions with Other Studies

\begin{tabular}{|c|c|c|c|c|c|}
\hline & Our study $\mathrm{N}=11$ & Yashita et al[ ${ }^{[1]}$ & Sheikh et al ${ }^{[3]}$ & Chauhan et al[2] & $\mathbf{N}$ ud din et al[4] \\
\hline Basal cell carcinoma & 1 & - & - & - & - \\
\hline $\begin{array}{l}\text { Squamous cell } \\
\text { carcinoma }\end{array}$ & 1 & 8 & - & 4 & 12 \\
\hline Pigmented nevus & 1 & 4 & 1 & 3 & 2 \\
\hline $\begin{array}{c}\text { Apocrine } \\
\text { hidrocystoma }\end{array}$ & 1 & - & - & - & - \\
\hline Conjunctival cyst & 1 & 19 & 3 & 9 & 2 \\
\hline $\begin{array}{c}\text { Benign fibrosseus } \\
\text { lesion }\end{array}$ & 1 & - & - & - & - \\
\hline Zygomycosis & 2 & & - & - & - \\
\hline Granulation tissue & 3 & 8 & 2 & 1 & - \\
\hline
\end{tabular}

Table 5: Comparison of Orbital Lesions with Other Studies

\begin{tabular}{|c|c|c|c|c|c|}
\hline & Our study & Yashita et al[ ${ }^{[1]}$ & Shaikh et $a^{[3]}$ & Ifeyinwa et a|[5] & N Ud Din et al[4] \\
\hline Basal cell carcinoma & 1 & - & - & - & - \\
\hline $\begin{array}{c}\text { Adenoid cystic } \\
\text { carcinoma }\end{array}$ & 1 & - & - & 1 & - \\
\hline Meningioma & 1 & - & - & - & - \\
\hline Zygomycosis & 3 & - & - & - & - \\
\hline $\begin{array}{l}\text { Arteriovenous } \\
\text { Malformation }\end{array}$ & 1 & - & - & - & - \\
\hline Retinoblastoma & - & 9 & 2 & 3 & 1 \\
\hline $\begin{array}{c}\text { Non - Hodgkins } \\
\text { lymphoma }\end{array}$ & - & 13 & 1 & - & 2 \\
\hline Schwannoma & - & 1 & 1 & - & - \\
\hline Hemangioma & - & 1 & 1 & 2 & 2 \\
\hline
\end{tabular}

Table 6: Comparison of Eyelid and Lacrimal Gland Lesions with Other Studies

\begin{tabular}{|c|c|c|c|c|c|c|}
\hline & Our study & Yashita et al ${ }^{[1]}$ & Shaikh et al[ ${ }^{[3]}$ & Ifeyinwa et al[ $^{[5]}$ & N Ud Din et al[4] & Hemalata et al[6] \\
\hline Basal cell carcinoma & 2 & 4 & 3 & - & - & - \\
\hline Sebaceous carcinoma & 2 & 25 & 3 & - & - & - \\
\hline Malignant melanoma & 1 & 5 & - & - & - & - \\
\hline Squamous cell carcinoma & 1 & 2 & 4 & - & - \\
\hline Pleomorphic adenoma & 1 & - & - & - & - & - \\
\hline
\end{tabular}


Our study Yashita et al ${ }^{[1]}$ Shaikh et al ${ }^{[3]}$ Ifeyinwa et al ${ }^{[5]}$ N Ud Din et al ${ }^{[4]}$ Hemalata et al ${ }^{[6]}$

\begin{tabular}{|c|c|c|c|c|c|}
\hline Myxoma & 1 & - & - & - & - \\
\hline Haemangioma & 4 & 8 & 5 & - & - \\
\hline Eosinophilic granuloma & 1 & - & - & - & - \\
\hline Seborrheic keratosis & 1 & 1 & 2 & - & - \\
\hline Epidermal cyst & 3 & 8 & 5 & - & - \\
\hline Chalazion & 2 & 8 & 9 & - & - \\
\hline Molluscum & 2 & 1 & - & - & - \\
\hline Arteriovenous malformation & 1 & - & - & - & - \\
\hline Dacryocystitis & 1 & - & - & - & - \\
\hline
\end{tabular}

and haemangioma was the diagnosis given in 4 cases, making it the most common benign lesion and the most common lesion overall in the eyelid. Among malignant lesions, we received 2 cases each of sebaceous carcinoma and basal cell carcinoma.

This was comparable to Yashita et al's study where 8 of the total benign lesions were that of haemangioma. ${ }^{[1]}$ Another study conducted by Abdi et al showed that 26 of their 122 benign eyelid lesions were vascular tumours. ${ }^{[14]}$ However the most common lesion overall in the eyelid was sebaceous carcinoma with 25 cases, which was also observed in similar studies conducted by Kumar et al, Sunderraj et al and Roh et al. ${ }^{[15,16,17]}$ There was a similar finding in a study conducted by Obata et al with maximum malignant eyelid lesions being diagnosed as sebaceous carcinoma. ${ }^{[12]}$ Rita et al in their study observed basal cell carcinoma as their most common malignant tumour, which was comparable to our study. ${ }^{[8]}$

\section{Conclusion}

Oculo-orbital lesions have a vast spectrum and are of varied presentations. Through our study we have tried to understand the frequency of occurrence of all lesions pertaining to eyeball, orbit and adnexa based on their histomorphology and present these uncommon and interesting lesions.

\section{References}

1. Gupta, Yashita et al.Clinico-Pathological Spectrum of Ophthalmic Lesions: An Experience in Tertiary Care Hospital of Central India. Journal of Clinical and Diagnostic Research.2017 Jan;11:09-13.

2. Chauhan SC et al. A histopathological study of ophthalmic lesions at a teaching hospital. National Journal of Medical Research.2012;2:133-36.

3. Sheikh, Shah Alam et al. Spectrum of ocular lesions in a tertiary care centre: a five year retrospective study. International Journal of Research in Medical Sciences.2016;4(5):1355-1360.
4. Ud Din N et al. Morphological Spectrum of Ophthalmic Tumors in Northern Pakistan. Journal of Pakistani Medical Association. January 2001; 51(1):19-22.

5. Onwubuya, Ifeyinwa Mary et al. Morphological Spectrum of Orbitoocular Diseases in a Tertiary Health Centre in Keffi, North Central Nigeria. Advances in Medicine.2015;2015:619414.

6. Krishnamurthy, Hemalatha et al. A clinicopathological study of lacrimal fossa lesions at a tertiary care centre. Journal of evolution of medical and dental sciences.2016; 6(91): 64316433 .

7. Kehinde, Monsudi et al. Histopathological study of ophthalmic tumours and masses in a tertiary hospital in north-western Nigeria. Annals of Clinical Sciences. March 2017; 2(1): 1-12.

8. Paul, Rita et al. Tumors of the eyelid - a histopathological study at tertiary care hospitals in Dhaka, Bangladesh. IMC J Med Sci. 2017; 11(1): 5-10.

9. Silas, Olugbenga et al. A Descriptive Study of Patterns of Conjunctival Lesions in Jos, Nigeria: A 10-year Retrospective Study. Annals of Tropical Pathology. January 2017;8(1) :37-41.

10. Vlad Costan, Victor et al. Histopathological and clinical characteristics of surgically removed cavernous venous malformations (so-called cavernous hemangiomas) of the orbit. REV.CHIM. (Bucharest).2019;70(1).

11. Tendler, Irwin et al. Primary extradural ectopic orbital meningioma. Ophthalmic Plastic and reconstructive surgery. 2017; 33(1):99-101.

12. Obata H, Aoki Y, Kubota S, Kanai N, Tsuru T. Incidence of benign and malignant lesions of eyelid and conjunctival tumours. Nippon Ganka Gakkai Zasshi. 2005;109(9):573-79.

13. Kapurdov A, Kapurdova M. Clinical, morphological and epidemiological data on eye tumours. Trakia J of Sciences.2010;8(4):34-39.

14. Abdi U, Tyagi N, Maheshwari V, Gogi R, Tyagi SP. J Indian Med Assoc. 1996 Nov; 94(11):405-9, 416, 418. 
15. Kumar R, Adhikari RK, Sharma MK, Pokharel DR, Gautam N. Pattern of ocular malignant tumours in Bhairahwa, Nepal. The Internet Journal of Ophthalmology and Visual Science. 2009;7(1).

16. Sunderraj P. Malignant tumours of the eye and adnexa. Indian J Ophthalmol. 1991 Jan-Mar; 39(1):6-8.

17. Roh KK, Lee JH, Youn DH. Clinical analysis of tumors of the eye and its adnexa. Korean J Ophthalmol. 1988 Jun; 2(1):27-31.
18. Marshall EC et al. Epidemiology of tumors affecting the visual system. Optom Clin. 1993; 3(3):1-16.

19. Mondal SK, Nag DR, Bandyopadhyay R, Adhikari A, Mukhopadhyay S. Conjunctival biopsies and ophthalmic lesions: A histopathologic study in eastern India. J Res Med Sci. 2012 Dec; 17(12):1176-9.

20. Thakur SK, Sah SP, Lakhey M, Badhu BP. Primary malignant tumours of eye and adnexa in Eastern Nepal. Clin Exp Ophthalmol.2003 Oct; 31(5):415-7.

\section{*Corresponding author:}

Dr. Urmi Chakravarty-Vartakm Postal, B-201, Himalayan Heights, Bhakti Park, Near IMAX Cinema, Wadala(E), Mumbai-400037 INDIA

Phone: +919833029703

Email: urmichakravarty@yahoo.co.in

Financial or other Competing Interests: None. 